\title{
後方インストゥルメント使用により手術を行った脊椎カリエスの検討
}

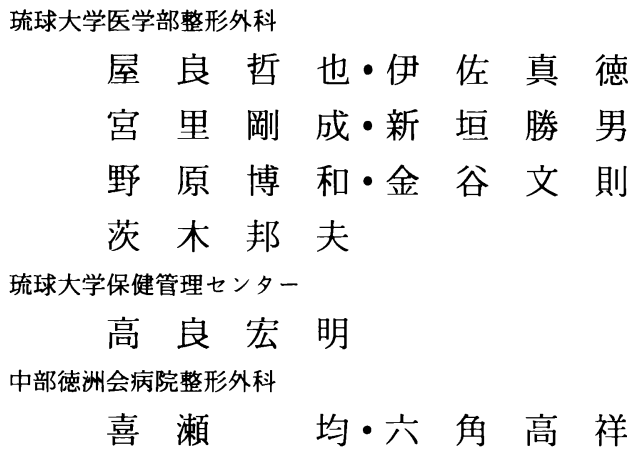

\section{Study of Spinal Tuberculosis Treated by Anterior Débridement, Fusion, and Combined Posterior Instrumentation}

\author{
Tetsuya Yara, Shintoku Isa, Takenari Miyazato, Katsuo Arakaki, \\ Hirokazu Nohara, Fuminori Kanaya, and Kunio Ibaraki \\ Department of Orthopedic Surgery, School of Medicine, University of the Ryukyus
}

\section{Hiroaki Takara}

Health Administration Center, University of the Ryukyus

Hitoshi Kise and Takayoshi Musumi

Department of Orthopedic Surgery, Chubu Tokushukai Hospital

Eleven patients with thoracic and lumbar tuberculosis were treated by anterior débridement and fusion combined posterior instrumentation. A one-stage surgery was done on seven patients and a two-stage surgery on four patients. Posterior instruments included seven ISOLA, three Luque rods with sublaminar wiring, and one Spine system. The average range of anterior fusion was 2.4 segments and that of the posterior fixation was 3.8 segments. Seven patients presented paraparesis before surgery and all improved after surgery. None showed persistent or recurrent tuberoculosis. Sagittal alignment, corrected after surgery, was not lost by more than 10 degrees in 10 patients but by 30 degrees in one patient treated with Luque rods. Solid bone union was obtained in all patients. Our study showed that anterior débridement and fusion combined with posterior instrumentation are useful for spinal tuberculosis.

Key words : spinal tuberculosis (脊椎カリエス), posterior instrumentation（後方インストゥルメ ンテーション), anterior débridement（前方掻爬） 
はじめに

脊椎カリエスは椎体破壊により麻痖や脊柱変形を生 じることが多く手術適応となりやすい，しかし前方掻 爬固定のみでは脊柱変形の矯正保持が困難なこともあ り，インストゥルメント使用による手術の有用性が報 告されている. 本研究の目的は脊椎カリエスに対する インストゥルメント使用手術の術後成績を調べ，本術 式の意義と問題点を検討することである.

\section{対象および方法}

対象は 11 例（女 10 例, 男 1 例）で全例細菌学的検 査で結核と診断された。年齢は $42 \sim 75$ 才（平均 59.5 才)であった。

手術は前方择爬・骨移植および後方インストゥルメ ント固定を行い，用いたインストゥルメントは ISOL A 7 例, Luque rod 3 例, Spine system 1 例であっ た. 後方手術の後, 前方手術を行ったのは 8 例で, う 5 5 例は一期的に， 3 例は二期的に行い，また前方手 術の後, 後方手術を行ったのは 3 例で，1例は一期的, 2 例は二期的手術であった．抗結核剤を 10 例は術前 から 1 例は術直後から投与し, 術後はコルセットを装 着した。

罹患椎と固定範囲については, 罹患椎は胸椎 5 例, 腰椎 6 例であり, 䍜患椎体数は $1 \sim 3$ （平均 2.1）で あった，手術固定範囲は前方が $1 \sim 4$ 椎間（平均 2.4 椎間) であり, 後方が $3 \sim 7$ 椎間（平均 3.8 椎間）で あった. 8 例で固定範囲は後方が前方より $1 \sim 4$ 椎間 長く, 3 例は前後ともに 2 椎間の Luque rod 固定で あった（図1).

麻痺 (Frankel の分類), 離床までの期間および CRP を調へ，画像は後方固定範囲の後弯角之骨癒合 について検討した．術後観察期間は 6 力月〜 4 年 2 力

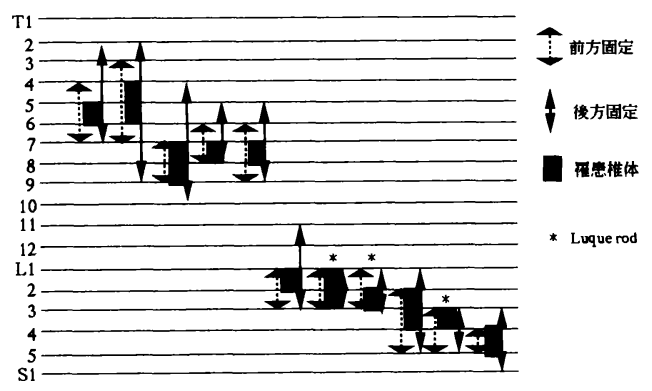

図 1 罹患椎之固定範囲
月（平均 2 年 3 カ月）であった.

結果

4 例は術前後ともFrankel E で麻瘏はなく， 7 例 は術前にD 2 例，C 5 例の麻疸を呈していたが, 術後 はいずれも 1 段階あるいは 2 段階の改善がみられた。

手術から離床までの期間は 9 〜 21 日（平均 14.2 日） であった。

$\mathrm{CRP}$ は術前 $0.1 \sim 5.6 \mathrm{mg} / \mathrm{dl}$ （平均 $2.4 \mathrm{mg} / \mathrm{dl}$ ）であ り, 術後 16 週までに 9 例がほぼ陰性化し， 2 例は低 下したが依然高值を示した。

後方固定範囲の Cobb 角は, 術前平均 10.5 度が術 直後 7.8 度, 経過観察時 12.5 度であった. 10 例は術 直後から観察時までの矯正損失は 10 度以内之固定位 を概ね保持できていたが，Luque rod 固定の 1 例は 術前 13 度が術後一 -3 度に矯正されたが観察時に 27 度 之後弯の増大がみられた（図 2 ).

骨癒合は全例に得られた。

\section{症例}

52 才女性. X 線像で $\mathrm{L} 1 / 2$ 椎間の狭小化之椎体終板 の不整および硬化像，MRI で椎体周囲と腰筋内の膿 瘍が認められ，針生検にて結核菌が検出された。 T11 からL 3 まで ISOLA により後方固定を行い，同日 L 1 からL 3 まで前方掻爬・腸骨移植を行った。術後腰 痛は消失し骨癒合も得られた（図 3 ).

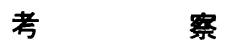

脊椎カリエスに対するインストゥルメント使用の意 義として一般的には早期離床, 骨瘉合率の向上, 十分 な前方择爬を可能としうる固定位の保持などが考えら れているが，著者らの症例も平均 14 日での離床，100 $\%$ の骨癒合率，4椎間前方择爬が可能であったこと， 11 例中 10 例の矯正損失が 10 度以内であったことか

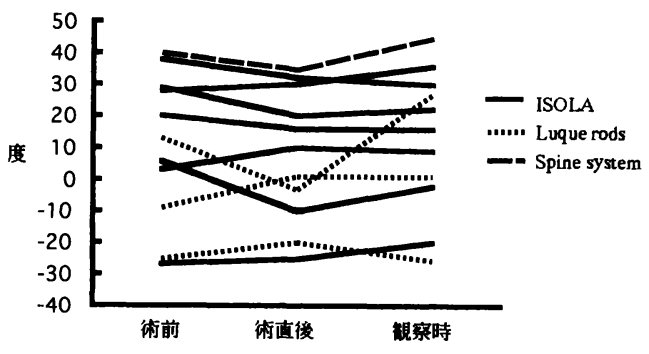

図 2 後方固定範囲の Cobb 角 


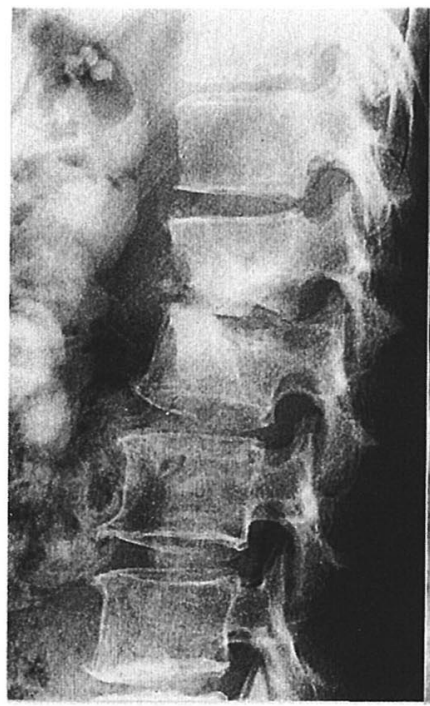

a

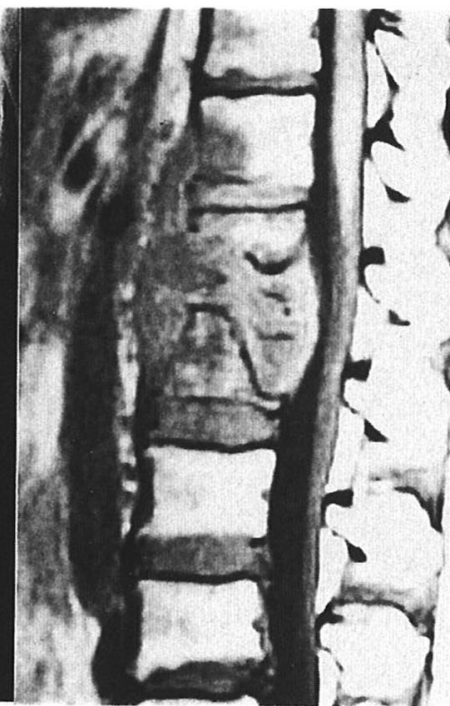

b

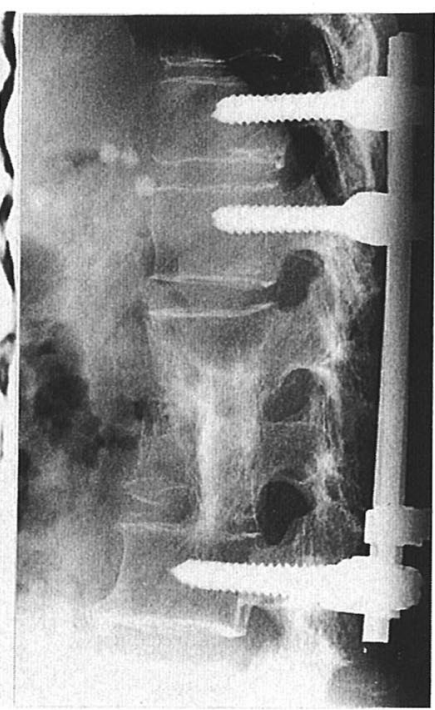

図 3 症例 59 才, 女性

a. 術前X線像 L $1 / 2$ 椎間の狭小化と椎体終板の不整および硬化像

b. 術前 MRI 椎体周囲之腰筋内に膿瘍

c. 術後X線像 T 11 L 3 の ISOLA 固定およびL $1 \sim$ L 3 前方掻爬・腸骨移植術を施行

ら，これらを概ね支持する結果であった。

脊椎カリエスに対するインストゥルメント使用の問 題点として, 感染の遷延あるいは再燃が危惧されるが, Ogaら ${ }^{1)}$ は結核菌は金属周囲に Biofilm の形成が少な いとし，司馬ら ${ }^{2)}$ は結核菌は菌の分裂・発育が緩徐な ためインストゥルメントによる感染増悪は少ないと述 べている，著者らの結果も感染の再燃は 1 例もなかっ たことから抗結核薬の全身投与下に十分な前方掻爬固 定を行えば脊椎カリエスに対してインストゥルメント の使用は禁忌とはならないと考えられた.

Luque rod 固定の 1 例で 30 度の矯正損失が生じた 理由として，2 椎間固定であったこと, Luque rod 固定は回旋や軸方向の力に弱いこと, 脊椎骨粗鬆症に より前方固定の支持性が不十分であったことなどが考 えられた. 矯正損失の対策としては固定範囲の延長あ るいは pedicle screw の併用などを考慮すべきと考 えられた.

$$
\text { ま と め }
$$

1. 奉椎カリエス 11 例に対して，前方掻爬・骨移
植に後方インストゥルメントを併用した手術法を行っ た。

2. 術前 11 例中 7 例に麻痺を認め, 術後全例が改 善した。

3. 固定性は概ね良好であり早期離床が可能であっ た.

4. 後方インストゥルメントの併用により十分な前 方掻爬が可能となり感染の再燃はなかった。

5. Luque $\operatorname{rod}$ 固定の 1 例で後弯の進行がみられ た.

\section{参考 文 献}

1) Oga M. et al. : Evaluation of the risk of instrumentation as a foreign body in spinal tuerculosis. Spine 18 : 1890-1894, 1993.

2）司馬 立ほ加：化膿性脊椎炎の再建術. 脊椎脊䯣 8 : 697-702, 1995. 